\title{
INTEGRASI TEKNOLOGI INFORMASI DAN KOMUNIKASI DALAM PEMBELAJARAN
}

\author{
Oleh: Muhammad Yaumi ${ }^{*}$
}

\begin{abstract}
This article aims at comprehensively assessing the extent to which the role of information and communication technology in supporting learning process and integration model is offered by considering various opportunities and constraints faced in the implementation of innovation diffusion. The use of Internet-based information communications technology such as Electronic Mail (E-mail), HP, Digital Cameras, MP3 Players, Web Sites, Wikipedia, YouTube, blogging, and podcasting are proven to be a source of learning and they are very important to be integrated. The integration of the information communication technology into learning can be applied through innovation and diffusion strategies and ASSURE model.
\end{abstract}

KEYWORDS: TIK, Diffusion, innovation, long-distance learning, eeducation, teaching media.

STUDI teknologi pendidikan telah mengalami perkembangan yang sangat pesat. Perkembangan ini dapat dilihat sejak diperkenalkan istilah media fisik seperti alat peraga, audiovisual, filmstrip, videotape berkembang menjadi video interaktif, satelit, teleconference, Internet, dan berbagai software pembelajaran lainnya. Sekarang dunia menjadi datar (the world is flat) kata Thomas L. Friedman seolah mengisyaratkan bahwa dunia pun sudah berubah seiring dengan perubahan dalam kehidupan manusia. Bahkan Evelyn Waugh berkata bahwa change is the only evidence of life, perubahan adalah pertanda kehidupan.

Sebagai suatu disiplin ilmu yang terlahir dari perpaduan berbagai disiplin lain seperti komunikasi, psikologi, teknologi, dan pendidikan, hadirnya perubahan dalam teknologi pendidikan tidak dapat dielakkan, bahkan menjadi bagian dari perancang perubahan itu sendiri. Menjadi perancang perubahan karena salah satu kajian teknologi pendidikan ada-

*Kandidat Doktor bidang Teknologi Pendidikan pada PPs UNJ ini adalah Dosen Tetap pada Fakultas Tarbiyah dan Keguruan UIN Alauddin Makassar. Memperoleh gelar M.Hum bidang Linguistik dari UNHAS dan M.A bidang Teknologi Pendidikan dari University of Northern Iowa USA. 
lah difusi inovasi yang menuntut adanya proses imitasi, adopsi, adaptasi, modifikasi, kreasi, inovasi, dan integrasi. Sedangkan, integrasi adalah suatu upaya untuk melakukan penggabungan dua atau lebih elemen guna menghasilkan inovasi baru. Dengan kata lain bahwa mengintegrasikan teknologi informasi ke dalam pembelajaran adalah suatu upaya untuk menggabungkan teknologi informasi dengan teori-teori pembelajaran guna menghasilkan cara dan strategi baru dalam melaksanakan pembelajaran.

Salah satu inovasi terbesar yang dialami bangsa ini di bidang komunikasi adalah dengan diluncurkan sistem komunikasi satelit domestik (satelit PALAPA) pada tanggal 16 Agustus 1976. Peluncuran satelit PALAPA tersebut telah memposisikan Indonesia menjadi suatu negara Asia pertama yang memprakarsai bangkitnya sistem telekomunikasi dunia yang mulai diperkenalkan di Amerika Serikat pada tahun 1960an. Sejalan dengan hal ini, Indonesia menjadi negara berkembang pertama yang memiliki satelit domestik atau negara kedua setelah Kanada yang telah menggunakan satelit domestik yang dikenal dengan ANIK. ${ }^{1}$ Bahkan Indonesia diklaim sebagai negara berkembang pertama yang mampu menggunakan dan sekaligus memiliki sistem komunikasi yang handal, enam tahun lebih awal dari India, dan sekitar satu dekade lebih dahulu dari negara-negara seperti Cina, Brazil, Meksiko, dan negara-negara Arab di Timur Tengah.

Kemajuan sistem telekomunikasi di Indonesia memang merupakan tuntutan hidup yang paling mendesak untuk menyatukan kelima pulau besar, 13,667 pulau kecil yang sudah diidentifikasi, dan sebanyak 1.000 pulau yang telah didiami. Kemudian sistem telekomunikasi yang dibangun juga telah membawa dampak yang sangat berharga bagi pengembangan dan pemerataan kesempatan pendidikan di Indonesia. ${ }^{2}$

Berdirinya Universitas Terbuka (UT) pada tahun 1984 adalah suatu upaya untuk mengakselerasi pengembangan sumber daya manusia di Indonesia. UT dibangun untuk menjalankan fungsi menyediakan akses bagi masyarakat Indonesia yang tidak dapat mengikuti pendidikan tinggi karena status ekonomi dan keterbatasan daya jangkauan secara geografis.

Dalam perkembangannya hingga saat ini, pendidikan jarak jauh menjadi simbol pembelajaran yang memadukan hasil rancangan teknologi canggih untuk tujuan menyampaikan pesan-pesan pendidikan. Hampir semua universitas di negara-negara maju dan beberapa universitas di Indonesia telah menawarkan sistem pendidikan jarak jauh melalui sistem pembelajaran e-learning. Sayangnya, pembangunan sistem telekomunikasi dan teknologi informasi di Indonesia tidak didesain khusus untuk maksud penyelenggaraan pendidikan yang berbasis teknologi informasi. Bahkan 
terkesan kedua sektor pendidikan dan telekomunikasi berjalan secara terpisah dan tidak saling terkait satu sama lain. Padahal negara memiliki kewajiban untuk mengakselerasi tumbuh dan berkembangnya sistem komunikasi yang efektif dan mengembangkan sumber daya manusia melalui jalur-jalur pendidikan. Oleh karena itu, tulisan ini menyoroti integrasi teknologi informasi ke dalam pembelajaran dengan melihat peranan teknologi informasi dan strategi integrasi teknologi ke dalam pembelajaran dengan berbagai kemungkinan dan kendala yang dihadapi dalam melakukan aktivitas integrasi.

\section{PERANAN TEKNOLOGI INFORMASI DAN KOMUNIKASI DALAM PEMBELAJARAN}

Teknologi Informasi dan komunikasi adalah ilmu yang mempelajari tentang desain, pengembangan, implementasi, manajemen sistem informasi yang berbasiskan komputer, khususnya aplikasi software dan hardware. ${ }^{3}$ Berdasarkan definisi ini, Teknologi Informasi dan komunikasi berhubungan dengan penggunaan komputer secara elektronik dan software komputer untuk mengubah, menyimpan, memproteksi, memproses, mentransmisi, dan memanggil kembali segala informasi secara aman.

Sejalan dengan definisi yang dikemukakan di atas, Association of educational communication technology (AECT) memberikan definisi tentang teknologi pembelajaran, yaitu teori dan praktek desain, pengembangan, pemanfaatan, manajemen, dan evaluasi terhadap proses dan sumber-sumber belajar. Teori yang dimaksud dalam definisi tersebut mencakup konsep, konstruksi, prinsip, dan proposisi yang berkontribusi pada batang tubuh ilmu pengetahuan. Sedangkan, praktek melibatkan aplikasi ilmu pengetahuan untuk mengatasi persoalan yang dihadapi. Lebih jauh teknologi informasi adalah teknologi yang menggabungkan komputasi (komputer) dengan jalur komunikasi yang membawa data, suara, atau gambar. Teknologi informasi ini merupakan subsistem dari sistem informasi terutama dalam tinjauan teknologi. ${ }^{4}$

Teknologi informasi dan komunikasi adalah studi atau penggunaan peralatan elektronika, terutama komputer, untuk menyimpan, menganalisis, dan mendistribusikan apa saja termasuk kata-kata,bilangan dan gambar. Hal ini mencakup perangkat keras, perangkat lunak untuk melaksanakan satu atau sejumlah tugas pemrosesan data seperti menangkap, mentransmisikan, menyimpan, mengambil dan memanipulasi atau menampilkan data. Selain itu, teknologi informasi tidak hanya terbatas pada teknologi komputer (perangkat keras dan perangkat lunak) yang digunakan untuk memproses dan menyimpan informasi, melainkan juga mencakup teknologi komunikasi untuk mengirimkan informasi. 
Perkembangan teknologi informasi telah membawa dampak yang begitu besar dalam dunia pendidikan. Setidaknya ada lima pergeseran yang dapat diidentifikasi dalam hubungannya dengan proses pembelajaran. Kelima pergeseran yang dimaksud dapat dijabarkan sebagai berikut:

- Pergeseran dari pelatihan ke perbaikan kinerja

- Pergeseran dari ruang kelas ke ruangan maya yang dapat berlangsung kapan dan di mana saja,

- Pergeseran dari kertas ke "on line" atau saluran,

- Pergeseran fasilitas fisik ke fasilitas jaringan kerja,

- Pergeseran dari waktu siklus ke waktu nyata. ${ }^{5}$

Pergeseran ini telah membawa pengaruh pada perubahan pola, metode, dan strategi penyajian pembelajaran di samping pendekatan yang digunakan juga ikut bergeser. Untuk memahami lebih jauh tentang pendekatan yang sering digunakan dalam pembelajaran, dapat dikaji melalui akronim waktu (time) dan tempat (place). ${ }^{6}$ Pendidikan yang menerapkan same time- same place (waktu yang sama - tempat yang sama), different time same place (waktu yang berbeda - tempat yang sama), same time - different place (waktu yang sama - tempat yang berbeda), dan different time - different place (waktu yang berbeda - tempat yang berbeda).

Model pendidikan traditional (face to face) mengambil ciri waktu yang sama - tempat yang sama, yang menjadi guru sebagai pusat belajar. Artinya, guru yang mengendalikan segala sesuatu yang terkait dengan pelaksanaan pendidikan. Pendidikan yang menggunakan pendekatan waktu yang berbeda - tempat yang sama menawarkan proses kemandirian dalam belajar seperti yang terjadi pada pusat belajar, media center, atau laboratorium komputer di mana siswa dapat memilih waktu menurut kesiapan mereka sendiri.

Kedua pendekatan pendidikan yang terakhir di atas, yakni: (1) waktu yang sama - tempat yang berbeda, dan (2) waktu yang berbeda - tempat yang berbeda menggunakan sistem telekomunikasi dalam penyampaian pesanpesan pendidikan. Kedua model inilah menggunakan komputer untuk menghubungkan ruangan kelas lokal yang menghadirkan guru dan murid dengan siswa/mahasiswa yang berada pada ruangan kelas jarak jauh. Selanjutnya, model pendidikan pada waktu yang sama - tempat yang berbeda, juga menggunakan basis satelit, video kompres, viber-optic. Sedangkan untuk model pendidikan pada waktu yang berbeda - tempat yang berbeda, menggunakan World Wide Web (www) untuk menjadi sumber belajar. Di sini siswa/mahasiswa dapat mengakses materi pembelajaran kapan, dan di mana saja mereka berada. Model yang terakhir ini disebut asynchrounous distance education, model pendidikan jarak jauh asingkronous. 
Penggunaan media-media komunikasi seperti telepon, komputer, internet, e-mail, dsb telah membangun suatu model interaksi yang terbangun dalam proses pembelajaran sekarang ini. Interaksi antara gu$\mathrm{ru/dosen} \mathrm{dan} \mathrm{siswa/mahasiswa} \mathrm{tidak} \mathrm{hanya} \mathrm{dilakukan} \mathrm{melalui} \mathrm{hubungan}$ tatap muka tetapi juga dilakukan dengan menggunakan media-media tersebut. Dengan adanya teknologi informasi sekarang ini guru/dosen dapat memberikan layanan tanpa harus berhadapan langsung dengan maha/siswa. Demikian pula maha/siswa dapat memperoleh informasi dalam lingkup yang luas dari berbagai sumber melalui cyber space atau ruang maya dengan menggunakan komputer atau internet. Hal yang paling mutakhir adalah berkembangnya apa yang disebut "cyber teaching" atau pengajaran maya, yaitu proses pengajaran yang dilakukan dengan menggunakan internet. Istilah lain yang makin populer saat ini ialah elearning yaitu satu model pembelajaran dengan menggunakan media teknologi komunikasi dan informasi khususnya internet.

E-learning merupakan satu penggunaan teknologi internet dalam penyampaian pembelajaran dalam jangkauan luas yang belandaskan tiga kriteria yaitu:

- E-learning merupakan jaringan dengan kemampuan untuk memperbaharui, menyimpan, mendistribusi dan membagi materi ajar atau informasi,

- Pengiriman sampai ke pengguna dilakukan melalui komputer dengan menggunakan teknologi internet yang standar,

- Terfokus pada pandangan luas tentang pembelajaran. ${ }^{7}$

Pemanfaatan E-learning dalam pembelajaran sebenarnya merupakan suatu langkah strategis untuk menggali potensi yang di bawah manusia sejak lahir karena dapat mengkonstruksi pengetahui melalui pemanfaatan berbagai sumber belajar. Melalui pembelajaran e-learning membangun manusia seutuhnya menjadi suatu hal yang sangat multak. Keutuhan manusia dapat dilihat dari aspek jasadiyah yang berkembang menjadi keterampilan yang harus dimiliki untuk bisa mengembangkan dan memanfaatkan teknologi. Di samping itu, penajaman aspek spiritual pun dapat diwujudkan melalui penggunakan teknologi untuk mengungkap hakekat sesuatu yang tidak dapat ditangkap oleh panca indera seperti yang dilakukan oleh Ary Ginanjar dalam program ESQnya. Dengan demikian, elearning telah mengangkat harkat dan martabat manusia sehingga bisa menjadi manusia seutuhnya baik menyangkut aspek jasadiyah maupun aspek rohaniahnya.

Pada saat ini e-learning telah berkembang dalam berbagai model pembelajaran yang berbasis TIK seperti: CBT (Computer Based Training), CBI 
(Computer Based Instruction), Distance Learning, Distance Education, CLE (Cybernetic Learning Environment), Desktop Videoconferencing, ILS (Integrated Learning System), LCC (Learner-Centered Classroom), Teleconferencing, WBT (Web-Based Training), dan sebagainya. Kalau demikian, apa pentingnya teknologi informasi dalam pembelajaran?

Untuk menjawab pertanyaan ini perlu memperhatikan manfaat teknologi informasi dalam pendidikan, seperti:

1. Mengembangkan E-Learning (E-edukasi)

2. Mendukung terciptanya kursus online

3. Menfasilitasi terbangunnya sistem tutorial bagi pendidikan jarak jauh

4. Membuka Perpustakaan Elektronik

5. Pembelajaran dengan menggunakan alat bantu komputer. ${ }^{8}$

Sejak tahun 2002 Pusat Teknologi Informasi dan Telekomunikasi (Pustekkom) bekerjasama dengan Direktorat Pendidikan Menengah dan Direktorat Pendidikan keterampilan mengembangan program e-learning yang disebut dengan "e-dukasi". Tujuan diselenggarakan program ini adalah untuk memperbaiki kualitas pendidikan menengah dan pendidikan keterampilan melalui penggunaan Internet. Kerjasama tersebut mendapat sambutan baik dari PT Telkom, bagian penelitian dan aplikasi teknologi Asosiasi Provider Indonesia, Jaringan informasi sekolah, dan Detik.com, dan pemantau teknologi informasi komunikasi. Pada tahap awal, materi pembelajaran diarahkan pada mata pelajaran Matematika, Fisika, Kimia, Biologi, Elektronik, dan teknologi informasi. Untuk menyelenggarakan kursus online, beberapa universitas swasta telah menyediakan perkuliahan melalui Internet untuk beberapa mata kuliah. Salah satu universitas swasta yang telah menawarkan kuliah online tersebut adalah Universitas Kristen Petra Surabaya. Sedangkan universitas yang telah melaksanakan sistem tutorial secara online adalah Universitas Terbuka Indonesia. ${ }^{9}$

Kerjasama di bidang program riset dengan menyediakan sistem kolaborasi melalui penggunaan teknologi informasi juga sudah dilaksanakan di beberapa Perguruan Tinggi seperti Institut Teknologi Bandung (ITB), Institut Pertanian Bogor (IPB), Universitas Gadjah Mada (UGM), dan Universitas Diponegoro. Sekarang ini, ada suatu jaringan perpustakaan elektronik yang bernama Jaringan perpustakaan Digital Indonesia yang menghubungkan perpustakaan elektronik dari perpustakaan pusat ITB, PPS ITB, Projek pengembangan Universitas-universitas Indonesia Timur (Projek CIDA) which is a network of electronic libraries from the ITB central library (Digital Library), the Post-Graduate Study Library of ITB, the Research Institute of ITB, perpustakaan pusat Universitas Brawijaya Malang, 
perpustakaan Universitas Muhammadiyah Malang, perpustakaan Universitas Islam (yang didukung oleh Universitas McGill Kanada) dan Data Bank Sentral Lembaga Ilmu Pengetahuan Indonesia (LIPI), Jakarta. Jaringan Perpustakaan digital Indonesia dimaksudkan untuk meningkatkan kualitas alumni universitas, meningkatkan sharing informasi antara institusi lembaga tinggi di Indonesia. Sayangnya, sistem jaringan perpustakaan seperti tersebut belum sampai ke wilayah timur Indonesia. ${ }^{10}$

Terakhir adalah pembelajaran dengan menggunakan alat bantu komputer dengan menggunakan program pembelajaran off-line, yang tidak tergantung pada jaringan Internet. Pusat Informasi dan Teknologi Komunikasi (PUSTEKKOM) telah mengembangkan materi pembelajaran berbasiskan alat bantu komputer yang secara interaktif dapat dipelajari oleh siswa tanpa atau dengan bantuan instruktur yang minim.

Terdapat beberapa jenis teknologi informasi yang biasa digunakan dalam pembelajaran, seperti; Surat Elektronik (E-mail), HP, Kamera digital, MP3 Players, Web Sites, Wikipedia, YouTube, Blogging, and Podcasting. Ketiga teknologi terakhir ini telah banyak mempengaruhi pandangan dan persepsi manusia seluruh dunia dengan begitu cepat. YouTube adalah website untuk mensharing video di mana pengguna dapat mengupload melihat, dan membagi video klip YouTube dibuat pada pertengahan bulan Januari 2005 oleh tiga pegawai paypal.11

Lebih jauh dijelaskan bahwa terdapat 100 juta video yang diputar setiap hari, 65.000 video baru yang dimuat, lebih dari 13 juta pengunjung setiap bulan, 58\% video di Internet dinonton melalui YouTube, Pengguna kebanyakan berumur 18 sampai 35 tahun, dan terjual sebanyak 1,6 juta dolar (US) pada tahun 2006.12

Blog atau webblog adalah suatu bentuk website yang menggunakan software tertentu yang latarnya sudah didesain. Blog adalah website di mana jalan masuknya telah ditulis menurut aturan kronologis dan umumnya dimunculkan bukan atau tidak mengikuti aturan kronologis. Blog adalah website yang digunakan untuk menerbitkan hasil karia pribadi. ${ }^{13}$ Dalam hubungannya dengan penggunaan web-blog, terdapat 12 juta orang Amerika menulis blog, 54 juta orang Amerika membaca blog, membolehkan penulis menulis untuk audiens, mudah didapat oleh setiap orang. Pada pertengahan tahun 2005 terdapat 70 juta web-blog telah dibuat, 6\% dari penduduk Amerika telah menulis $b \log , 16 \%$ dan telah membaca blog-blog yang ada. ${ }^{14}$

Podcasting adalah website yang dapat digunakan untuk menyimpan dan merancang radio sendiri. File audionya disimpan berdasarkan 
subskrepsi yang dapat dijadikan sebagai tempat teater penulis dan dapat merekam proses belajar mengajar dalam ruangan kelas. Selain podcasting terdapat juga Google Earth yang merupakan peta browser geografi - suatu alat yang sangat bagus untuk melihat menciptakan, dan mensharing file-file interaktif yang berisi informasi lokasi khusus secara visual. ${ }^{15}$ Google earth juga telah mampu mendeteksi berbagai fenomena alam yang terjadi di belahan bumi mana pun di dunia ini. Seperti yang diamati sendiri oleh penulis dalam mendeteksi gunung berapi yang terdapat dalam tingkat kedalaman 3000 kaki di bawah laut di sekitar kota Bengkulu. Ketika surat kabar Bengkulu Post memberitakan bahwa terdapat gunung berapi di bawah laut di kota Bengkulu, dengan bantuan satelit yang terdapat dalam google earth, kita dengan mudah menyaksikan tempat beradanya gunung berapi yang dimaksud. Jika, google earth diintegrasikan ke dalam pembelajaran geografi misalnya, maka mahasiswa akan dapat melakukan investigasi dengan mudah apa yang secara goegrafis dapat ditelusuri.

\section{INTEGRASI TEKNOLOGI INFORMASI DAN KOMUNIKASI DALAM PEMBELAJARAN}

Secara pragmatis, konsep E-learning telah menjadi bagian yang tak terpisahkan dengan model pembelajaran multisumber sekarang ini. Namun, upaya untuk mengintegrasikan teknologi ke dalam pembelajaran masih menemui kendala yang begitu besar. Kendala yang dimaksud terkait dengan tidak seiringnya kemajuan di bidang teknologi informasi di satu sisi dengan kemajuan di bidang teori-teori pendidikan di sisi lain. Akibatnya, sering kedua disiplin ilmu ini berjalan secara terpisah. Artinya, keinginan para teknolog informasi untuk mengintegrasikan teknologi ke dalam pembelajaran terhambat dengan tidak digunakannya teori-teori pembelajaran dalam teknologi informasi. Sebaliknya, kemampuan untuk mengembangkan teori-teori pembelajaran yang dilakukan dalam pendidikan sering dihambat oleh terbatasnya pengetahuan dan keterampilan dalam menggunakan teknologi informasi.

Selanjutnya, pemanfaatan teknologi informasi dalam pembelajaran belum banyak mengintegrasikan Surat Elektronik (E-mail), Kamera digital, MP3 Players, Web Sites, Wikipedia, Podcasting, YouTube, Blogging, dan sistem teleconference yang memanfaatkan software online seperti Skype. Email hanya digunakan sebagai media komunikasi untuk mensharing informasi dan menanyakan khabar. Begitu pula ruang chatting (komunikasi sinkronous secara elektronik melalui Internet) belum didesain khusus untuk menyampaikan pesan-pesan pendidikan secara formal. Juga, pemanfaatan video pembelajaran dan berbagai jenis video lainnya yang tersimpan 
dalam You Tube yang berfungsi untuk mensharing video di mana pengguna dapat mengupload, melihat, dan membagi video klip, belum terintegrasi dengan baik dalam pembelajaran. Pemanfaatan youtube baru sebatas mengupload untuk sekedar menyimpan hasil rancangan video agar pihak lain yang berada di mana pun di dunia dapat mengakses. Sayangnya, penggunaan You Tube ini di Indonesia belum dirancang dan diintegrasikan untuk kebutuhan pembelajaran yang sewaktu-waktu dapat diakses. Hampir semua rancangan video baru merupakan wadah hiburan semata. Walaupun teknologi informasi telah diintegrasi pada pembelajaran pada beberapa sekolah, berbagai aspek seperti agama, umur, kultur, latar belakang sosio-ekonomi, interes, pengalaman, level pendidikan menjadi hal yang sangat diperhitungan. Hal ini dilakukan untuk meminimalisir ketidakberterimaan penggunakan teknologi karena alasan yang sifatnya ideologis dan dogmatis.

Di samping itu, pada saat pengembangan sistem pembelajaran, sering tidak memperhatikan tentang desain dan pengembangan sistem, interactivity, active learning, visual imagery, dan komunikasi yang efektif. Padahal proses pengembangan pembelajaran untuk pendidikan jarak jauh harus melalui tahap perancangan, pengembangan, evaluasi, dan revisi. Dalam mendesain pendidikan jarak jauh yang efektif, harus diperhatikan, bukan hanya tujuan, kebutuhan, dan karakteristik dosen dan mahasiswa atau guru dan siswa, melainkan juga kebutuhan isi dan hambatan teknis yang mungkin terjadi. Revisi dilakukan berdasarkan masukan dari instruktur, spesialis pembuat isi, dan mahasiswa selama dalam proses berjalan. Keberhasilan sistem pendidikan jarak jauh antara lain ditentukan oleh adanya interaksi antara dosen dan mahasiswa, antara mahasiswa dan lingkungan pendidikan, dan antara mahasiswa. Partisipasi aktif peserta pendidikan jarak jauh mempengaruhi cara bagaimana mereka berhubungan dengan materi yang akan dipelajari.

Pembelajaran lewat televisi dapat memotivasi dan merangsang keinginan dalam proses pembelajaran. Namun, jangan sampai terjadi distorsi karena adanya hiburan. Harus ada penyeleksian antara informasi yang tidak berguna dengan yang berkualitas, menentukan mana yang layak dan tidak, mengidentifikasi penyimpangan, membedakan fakta dari yang bukan fakta, dan mengerti bagaimana teknologi dapat memberikan informasi berkualitas.

Desain instruksional dimulai dengan mengerti harapan pemakai, dan mengenal mereka sebagai individual yang mempunyai pandangan berbeda dengan perancang sistem. Dengan memahami keingingan pemakai maka dapat dibangun suatu komunikasi yang efektif. 
Untuk dapat mengintegrasikan semua komponen teknologi informasi perlu dijabarkan beberapa teori dan model integrasi teknologi ke dalam pembelajaran. Salah satu teori yang dapat digunakan dalam integrasi teknologi ke dalam pembelajaran adalah teori difusi inovasi. Teori ini bukan saja memberikan kerangka dasar dalam mengadopsi dan mengintegrasi, melainkan juga beberapa strategi dan skenario yang dapat memberikan kemudahan dalam melakukan integrasi. Dalam mengintegrasikan teknologi ke dalam pembelajaran, para integrator atau adopter perlu malakukan lima fase dalam integrasi, yakni (1) menentukan keuntungan relatif, (2) menentukan tujuan dan penilaian, (3) mendesain strategi integrasi, (4) mempersiapkan lingkungan pembelajaran, (5) mengevaluasi dan merevisi strategi integrasi. ${ }^{16}$

Dalam menentukan keuntungan relatif, perlu menjawab pertanyaan seperti "mengapa menggunakan metode berdasarkan teknologi?" Pertanyaan ini harus dijawab dengan menganalisis pertama, tingkat keberterimaan (compatibility) baik dilihat dari perspektif nilai-nilai budaya dan keyakinan maupun dari sudut pandang yang menggambarkan kebaikan bagi guru, murid, dan seluruh komponen yang terkait. Juga terkait dengan kesesuaian antara teknologi yang diintegrasikan dengan kondisi real lingkungan di mana diterapkan teknologi. Kedua, tingkat kesulitan (complexity) yang menggambarkan kemudahan dalam menggunakannya untuk kebutuhan pembelajaran. Ketiga, ketercobaan (triability) dalam penerapaannya yang merujuk pada apakah sudah dapat diterapkan sesuai kondisi lingkungan sebelum mengambil keputusan final. Keempat, keterhandalan dalam pengamatan yang merujuk pada tingkat keberterimaan pada pihak lain yang sudah pernah melaksanakan uji coba.

Integrasi teknologi juga perlu menentukan tujuan dan penilaian yang dapat dikembangkan dengan menjabarkan pertanyaan bagaimana mengetahui bahwa pemelajar sudah melakukan aktivitas belajar? Untuk merancang tujuan dan menentukan penilaian dapat menggunakan daftar check list kinerja, check list kriteria, dan rubrik. Dengan menggunakan instrumen tujuan dan evaluasi tersebut, maka akan diketahui kinerja yang bagaimana yang diinginkan kepada pemelajar untuk dikuasai, cara yang paling sesuai untuk mengukur kemampuan dan kinerja pemelajar, instrumen yang akan digunakan apakah harus dibuat atau hanya dikembangkan saja, dan menentukan metode apa yang mungkin bisa digunakan untuk mengukur dan menilai keberhasilan.

Untuk memudahkan dalam mendesain strategi integrasi teknologi ke dalam pembelajaran, perlu menjawab pertanyaan strategi dan Kegiatan 
belajar yang bagaimana yang mungkin bisa berjalan dengan baik? Dalam menjawab pertanyaan ini perlu dikaji berbagai pendekatan dalam pembelajaran, pendekatan yang digunakan dalam implementasi kurikulum, pengelompokkan, dan sekuensi. Hal ini akan mengarahkan pada bentuk aktivitas yang digunakan seperti metode langsung, konstruktivis, atau penggabungan dari kedua metode itu. Mungkin juga apakah dalam melaksanakan kegiatan tersebut dilakukan secara individu, berpasangpasangan, kelompok kecil, kelompok besar, atau seluruh kelas. Lebih lanjut, apakah perlu dipersiapkan strategi dan model penilaian tersendiri untuk menangani pemelajar minoritas dalam suku, atau berkebutuhan khusus. Hal-hal seperti ini perlu dipikirkan ketika mengintegrasikan teknologi ke dalam pembelajaran.

Dalam mempersiapkan lingkungan yang digunakan dalam mengintegrasi teknologi, perlu mempertimbangkan pertanyaan berikut: adakah tempat-tempat yang memiliki kondisi tertentu untuk menerapkan teknologi yang diintegrasikan? Tentu saja, hal ini berkaitan langsung dengan jumlah komputer, software, hardware, peralatan dan media atau teknologi lain yang mendukung proses pembelajaran. Jangka waktu yang harus dipersiapkan dan disusun dalam bentuk schedule. Di samping itu, aspek privacy dan safety yang mendukung keamanan dalam belajar. Terkadang, unsur-unsur yang mengandung kerahasiaan dan keamanan luput dari pengawasan. Akibatnya, kebebasan anak-anak di bawah umur sering dengan mudah mengakses berbagai situs yang seharusnya untuk ukuran umur mereka belum dapat mengaksesnya.

Terakhir, dalam melakukan evaluasi dan revisi perlu memperhatikan pertanyaan apa yang telah dilakukan dengan baik? apa yang harus diperbaiki? Pertanyaan ini dapat dijawab dan dikaji lebih jauh dengan menganalisis problem pembelajaran yang harus diselesaikan, jenis aktivitas yang menggambarkan berbagai strategi yang mungkin sangat cocok untuk menyelesaikan persoalan, perbaikan kegiatan, instrumen untuk mengumpulkan data, hasil yang diperoleh dalam menggunakan teknologi, cara alternatif yang lebih baik, sesuatu yang harus diperbaiki untuk memperoleh hasil yang lebih baik. Semua hal ini harus dikaji lebih mendalam untuk memberikan gambaran yang jelas tentang hasil yang diperoleh dan digunakan melakukan revisi, perbaikan, atau menggantinya dengan berbagai alternatif strategi lainnya.

Hampir sama dengan kelima fase ini, model integrasi yang digambarkan melalui akronim ASSURE menawarkan enam langkah; (1) menganalisis pebelajar, (2) menyatakan tujuan (umum dan khusus), (3) menyeleksi metode, media, dan materi, (4) memanfaatkan media dan materi, 
(5) meminta partisipasi pemelajar, dan (6) mengevaluasi dan merevisi. ${ }^{17}$ Keenam langkah ini pada dasarnya memiliki strategi yang sama dengan lima fase yang terdapat dalam teori difusi inovasi, namun berbeda dalam objek dan tujuan digunakannya. Teori difusi inovasi dapat digunakan untuk melalukan integrasi, adopsi, dan membuat yang baru. Sedangkan teori ASSURE hanya digunakan dalam mengembangkan dan mengadopsi teknologi yang sudah tersedia.

Walaupun kedua teori difusi inovasi dan teori ASSURE telah diperkenalkan dalam upaya untuk melakukan integrasi teknologi ke dalam pembelajaran, namun bukan berarti segala yang terkait dengan penggunaan teknologi informasi dalam pembelajaran, dengan sendirinya dapat teratasi. Terdapat beberapa kendala fundamental yang dapat menghambat lajunya program integrasi teknologi informasi ke dalam pembelajaran. Kendala tersebut terkait dengan; (1) kurangnya materi pembelajaran yang berbahasa Indonesia, (2) kurangnya kemampuan bahasa Inggris, (3) akses Internet belum merata, (4) belum siapnya guru, dosen, dan staf pengajar, (5) membutuhkan waktu yang panjang untuk belajar mengintegrasikan teknologi informasi ke dalam pembelajaran, (6) kesulitan perijinan (jika membangun sekolah atau universitas yang serba digital dan cyber). ${ }^{18}$

Ketersediaan materi pembelajaran dalam Bahasa Indonesia memang masih sangat terbatas. Inisiatif beberapa sekolah dan perguruan tinggi yang telah memanfaatkan dan mengintegrasikan teknologi informasi ke dalam pembelajaran di Indonesia lebih banyak menggunakan materi dari luar negeri. Akibatnya, tidak menutup kemungkinan ada sekolah dan universitas di Indonesia hanya menjadi agen atau menjalankan outlet bagi perguruan tinggi di luar negeri. Masih perlu inisiatif-inisiatif untuk membuat materi pembelajaran dalam bentuk digital yang berbahasa Indonesia untuk mengurangi ketergantungan positif dari negara-negara lain di dunia.

Kemampuan berbahasa Inggris bagi para adopter dan integrator belum memadai. Karena materi dalam bahasa Indonesia belum banyak tersedia, maka harus menggunakan materi dalam bahasa Inggris seperti halnya penggunaan buku teks berbahasa Inggris yang saat ini dilakukan pada hampir seluruh universitas di Indonesia. Ironisnya, keinginan untuk menggunakan buku-buku teks yang berbahasa Inggris begitu besar, tetapi tidak disertai dengan kemampuan memahami bahasa Inggris yang memadai yang pada gilirannya menyebabkan pemerolehan ilmu menjadi tidak terserap dengan baik, hanya diperoleh sisi permukaannya saja sehingga terkesan sangat dangkal dan parsial. Untuk itu pemahaman bahasa Inggris merupakan salah satu kebutuhan yang harus dikuasai oleh mahasiswa. 
Aksesibilitas internet belum merata dan masih relatif mahal di beberapa tempat. Meskipun kecenderungan akses Internet mulai menyebar dengan harga yang relatif murah, namun pada kenyataannya masih banyak tempat di Indonesia yang belum memiliki saluran telepon. Bahkan beberapa tempat masih belum miliki jaringan listrik yang memadai. Sedangkan, yang sudah memiliki jaringan listrik masih dihambat dengan kecilnya persediaan pasokan sehingga pemadaman listrik secara bergilir pun tidak dapat dihindari.

Kemampuan Guru, dosen, atau staf pengajar untuk mengintegrasi dan memanfaatkan teknologi informasi ke dalam pembelajaran belum merata. Bahkan tidak sedikit tenaga kependidikan yang belum tersentuh oleh teknologi. Keadaan ini menyebabkan proses penyampaian materi pembelajaran menjadi terhambat. Semoga keterbatasan kemampuan bagi para pelaku pendidikan dapat berangsur-angsur terselesaikan. Namun masalah ini tidak dapat berkurang begitu saja tanpa ada usaha untuk meminimalisirnya. Untuk itu perlu ada upaya untuk meningkatkan kemampuan guru, dosen, atau staf pengajar.

Ketersediaan waktu bagi para guru, dosen, atau staf pengajar harus diarahkan pada penguasaan teknologi karena proses belajar teknologi membutuhkan waktu yang cukup memadai. Kesibukan untuk menangani beberapa mata pelajaran/mata kuliah dan kesibukan membantu perguruan tinggi dan sekolah lain atau mungkin berbagai kesibukan lain di luar tugas utama seharusnya dapat diminimalisir guna dapat mengagendakan dan membuat time schedule untuk memperdalam pengetahuan dalam menggunakan teknologi dan bahkan cara mengintegrasikan ke dalam pembelajaran.

\section{SIMPULAN}

Berdasarkan uraian dan penjelasan di atas, beberapa hal mendasar mengenai integrasi teknologi dalam pembelajaran dapat disimpulkan sebagai berikut:

1. Integrasi teknologi informasi yang berkembang di Indonesia masih berada dalam tataran imitasi, adopsi, dan adaptasi seperti pemanfaatan teknologi ke dalam pembelajaran. Integrasi yang mengarah kepada modifikasi, difusi, dan kreasi inovasi teknologi informasi belum dapat dilakukan baik oleh praktisi telematika maupun oleh ahli pendidikan. Kedua praktisi telematika dan ilmuan pendidikan masih berjalan secara terpisah dan belum bekerja secara kolaborasi untuk membangun satu kekuatan dalam melakukan modifikasi, difusi, dan kreasi inovasi teknologi informasi yang terintegrasi dalam pembelajaran padahal pem- 
belajaran melalui E-learning merupakan suatu kebutuhan yang sangat mendesak dalam rangka membangun manusia Indonesia seutuhnya.

2. Walaupun teori difusi inovasi telah banyak dilakukan dalam pemanfaatan teknologi informasi dalam pembelajaran, berbagai kendala seperti kurangnya materi pengajaran yang berbahasa Indonesia, terbatasnya kemampuan bahasa Inggris, akses Internet yang belum merata, belum siapnya guru,dosen, dan staf mengajar, dan keterbatasan waktu dalam memperdalam pengetahuan dan keterampilan teknologi masih dominan dihadapi oleh hampir seluruh ahli telematika dan ahli pendidikan.

\section{CATATAN AKHIR}

1. Yusufhadi Miarso, Menyemai Benih Teknologi Pendidikan, Jakarta: Kencana Prenada Media Group. 2007, h. 468.

2. M. D. Ibrahim, Planning and development of Indonesia's domestic communications satellite system Palapa, Online Journal of Space Communication, 8. http://satjournal.tcom.ohiou.edu/issue8/his marwah. html, 2005, h. 10.

3. Wikipedia, Information Technology, 2009, http://en.wikipedia.org/wiki /Informationtechnology, h. 1.

4. Seels and Richey, Instructional Technology, Bloomington, IN: Association For Educational Communications and Teschnology, 1994, h. 1.

5. M. J. E. Rosenberg, Learning: Strategies for Delivering Knowledge in the Digital Age, New York: McGraw Hill, 2001, h. 28.

6. M. Simonson, S. Smaldino, M. Albright, \& S. Zvacek, Teaching and Learning at a Distance, New Jersey: Pearson Education., Inc. 2003, h. 8.

7. Rosenberg, op.cit., h. 29.

8. Yuhetty, ICT dalam Pendidikan, 2008, http://ulongiroel.blogspot.com/, h. 4.

9. Muhammad Yaumi, Using Distance Education to Deliver English Instruction in Indonesia, Research Paper pada University of Northern Iowa, 2006, h. 21.

10. Ibid., h. 22.

11. Wikipedia, You Tube, 2009, http://www.google.co.id/search?hl=en\&defl=en $\& q=$ define:You+Tube\&sa=X\&oi=glossaryd efinition\&ct=title, h. 1 .

12. Leigh Zeitz, Using Information Technology into the Classroom Setting, Makalah disampaikan pada acara Teleconference Stadium General di Univarsitas Muhammadiyah Pare-Pare Sulawesi Selatan, tanggal 3 September 2007, h. 3.

13. Wikipedia, Web-blog. 2009, http://en.wikipedia.org/wiki/Blog, h. 1.

14. Leigh Zeitz, op.cit., h. 5.

15. Wikipedia, Podcast, 2009, http://en.wikipedia.org/wiki/Podcast, h. 1.

16. M. D. Roblier, Integrating Educational Technology into Teaching, Third Edition, Upper Saddle River, New Jersey: Pearson Education Inc.H. 2004. P. E-1.

17. R. Heinich, M. Molenda, J. D. Russell, \& S. E. Smaldino, Instructional media and technologies for learning, Seventh edition, Upper Saddle River, New Jersey: Pearson Education. 2002. h. 52. 
18. Budi Rahardjo, Cyber University, Teknologi Informasi, dan Perguruan Tinggi di Indonesia, 2002, http://www.cert.or.id/ budi/articles/cyber-uni/cyber-uni. pdf, h. 9 .

\section{DAFTAR PUSTKA}

Heinich, R., M. Molenda, J. D. Russell, \& S. E. Smaldino, Instructional media and technologies for learning. Seventh edition. Upper Saddle River, New Jersey: Pearson Education. 2002.

Ibrahim, M. D., Planning and development of Indonesia's domestic communications satellite system Palapa, Online Journal of Space Communication, http:// satjournal.tcom.ohiou.edu/issue8/hismarwah .html), 2005.

Miarso, Yusufhadi, Menyemai Benih Teknologi Pendidikan, Jakarta: Kencana Prenada Media Group, 2007.

Pijpers, R.E., K. Van Montfort \& F. J. Heemstra, Acceptatie van ICT: Theorie en een veldonderzoek onder topmanagers, Bedrijfskunde, 2002, 74, 4 http:/ / www.cw.utwente.nl/theorieenoverzicht/Theory\%20clusters/Communication\%20and \%20Information\%20Technology/DiffusionofInnovationsTheory.doc/.

Roblier, M.D., Integrating Educational Technology into Teaching, Third Edition, Upper Saddle River, New Jersey: Pearson Education Inc.H., 2004.

Rosenberg, M.J. E., Learning: Strategies for Delivering Knowledge in the DigitalAge, New York: McGraw Hill. 2001.

Seels and Richey, Instructional Technology, Bloomington, IN: Association For Educational Communications and Teschnology. 1994.

Simonson, M., Smaldino, S., Albright, M., \& Zvacek, S. Teaching and learning at a distance. New Jersey: Pearson Education., Inc. 2003.

Wikipedia, Information Technology, 2009, http://en.wikipedia.org/wiki/Information technology.

Wikipedia, You Tube, 2009, http://www.google.co.id/search?hl=en\&defl $=$ en\&q=define:You+Tube\&sa $=X \& o i=$ glossary definition\&ct=title.

Wikipedia, Web-blog, 2009, http://en.wikipedia.org/wiki/Blog.

Wikipedia, Podcast, 2009, http://en .wikipedia.org/wiki/Podcast.

Williams dan Sawyer dalam Total Sarana Edukasi, 2007, http://www.total .or. id/info.php?kk=teknologi\%20informasi.

Yaumi, Muhammad, Using Distance Education to Deliver English Instruction in Indonesia, Research Paper pada University of Northern Iowa, 2006.

Yuhetty, ICT dalam Pendidikan, 2008, http:/ / ulongiroel.blogspot.com/.

Zeitz, Leigh, "Using Information Technology into the Classroom Setting", Makalah disampaikan pada acara Teleconference Stadium General di Univarsitas Muhammadiyah Pare-Pare Sulawesi Selatan pada tanggal 3 September 2007. 